\title{
Non isolated coupled converter tied voltage source inverter drive
}

\author{
A. Suresh Kumar ${ }^{1}$, R.K. Pongiannan ${ }^{2}$, C. Bharatiraja ${ }^{3}$, Adedayo Yusuf ${ }^{4}$, N. Yadaiah $^{5}$ \\ ${ }^{1}$ Department of Electrical and Electronics Engineering, Samskruti college of Engineering and Technology, India \\ 2,3 Department of Electrical and Electronics Engineering, SRM Institute of Science and Technology, India. \\ ${ }^{3,4}$ Department of Electrical Engineering, University of Johannesburg, South Africa. \\ ${ }^{5}$ Department of Electrical and Electronics Engineering, JNTUHCEH, India
}

\begin{tabular}{l} 
Article Info \\
\hline Article history: \\
Received Nov 15, 2018 \\
Revised Jan 29, 2019 \\
Accepted Feb 3, 2019 \\
\hline
\end{tabular}

Keywords:

High step DC to DC converter, impedance networks, voltage source inverter.

\begin{abstract}
The voltage source inverters (VSI) are ever required section in the AC motor drive and power system interface. The electrical drive segment, the VSI based drives are unavoidable and they are closely operated with induction motor, permanent magnate synchronous motor and BLDC motor. These drives are normally needed high torque-power characters. Hence, the input DC-link side voltage is increased with help of increasing input $\mathrm{AC}$ in the rectifier input. However, this causes the power quality disturbance in the $\mathrm{AC}$ main and DC-link. In order to go for a increasing the AC voltage, the rectifier out is connected with DC to DC boost converter and they are increasing the DC voltage to meet out the drive DC-link voltage demand. With this aim, the paper proposes the idea to connect high step non-isolated high gain coupled DC to DC converter with three phase VSI for drives applications. The proposed converter has an ability to increase the voltage five times and the counter winding arrangement ratio of the converter is help for the further increase of gain. Inn this interface the front end DC to DC converters inductors are charged by making the short circuit with inverter switching. The converter voltage gain is controlled by shoot through of the VSI switch (converter gain directly proportional to inverter shoot through). The proposed converter has a higher degree of freedom in their values of winding and output voltage. Hence, the DC-link voltage of the inverter can be extended in any level. The operation principle and modes of the proposed DC to DC Source tied VSI is analyzed and simulated using MATLABSimulink software simulation. The laboratory based small scale power circuit is developed with help of control algorithm. The entire implementation is done through PIC microcontroller platform. The deign Investigation, system simulation and experimentation confirming the proposed DC to DC converter tied VSI drive system.
\end{abstract}

Copyright (c) 2019 Institute of Advanced Engineering and Science. All rights reserved.

\section{Corresponding Author:}

Dr. C.Bharatiraja,

Department of Electrical and Electronics Engineering,

SRM Institute of Science and Technology (formerly known as SRM University),

Kattankulathur Campus, Chennai, India - 603203.

Email: bharatiraja.c@ktr.srmuniv.ac.in

\section{INTRODUCTION}

The voltage source inverters (VSI) based electrical drives are the unavoidable segment/ device in the industrial drives. Theses drives are normally deigned for induction motor, permanent magnet synchronous motor, BLDC motor, and special machines category. These drives are normally needed high torque-power characters. Hence, the input DC-link side voltage is increased with help of increasing input AC in the rectifier input. However, this causes the power quality disturbance in the AC main and DC-link. In current 
era electrical vehicles (EVs) are taken high concertation to reduce the CO2 emissions [1]. These EVs are using low and medium power electrical drives for their accelerations. In order to go for a increasing the AC voltage, the rectifier out is connected with DC to DC boost converter and they are increasing the DC voltage to meet out the drive DC-link voltage demand. These converter are basically classified into two group (isolated and non-isolated). Isolated converters are using transformer and occupy more space. However, the through the non-isolated converters deign is little difficult and they are well suitable for two stage power conversion based drive systems. With this aim, the paper proposes the idea to connect high step non-isolated high gain coupled DC to DC converter with three phase VSI for drives applications [3-11].

Recently numerous research papers published in DC to DC power converters. The applications of the DC to DC converters are widely used in various application in low power to high power level. They are mainly focused improvement of voltage gain and smooth current response in continues current signature. The efficiency, power handling, stability is an additional characterization for converters design. The controller arguments is related with the converters steady state performance improvement to alive continuous voltage and current responses. In particularly for the two stage power conversion drive system, there DC to DC converter looking for a high reliability and efficiency [5-18]. The VSI fed drive system efficiency aim to have a variable DC- bus voltage for VSI is to get better the system controllability and efficiency by boosting the DC-bus voltage for the period of flux-weakening in the motor drive. In flux-weakening operation state, a restricted DC-bus voltage results in involving directly control the flux. To achieve this high voltage gain DCDC converter employed with inverter. As a result of the variable DC-bus voltage no d-axis current is compulsory in the mid-range high speed. Thus, the copper losses get reduced which getting better system efficiency. The High step voltage gain DC to DC converter is a principle follows Z-source network [6].

Few research attempt is made for using MLIs for PV connected stand alone and grid connected applications as well [7-10]. There are many research has been reported in Z-source network, which are mainly developed to offer an efficient power conversion with an extensive voltage gain [11], higher voltage boosting through the coupled magnetic circuit, inductor arrangement and shoot-through time [12-14]. The coupled magnetic circuit based DC to DC conversion, verity of converter is proposed [15-23]. The work is also carried out for maintain the voltage stability for adding the battery across the capacitor. Through these idea is improving the system stability, the cost and size does not comprehend [22]. The authors, Y. P. Siwakoti et.al in [23] suggested the interesting high step voltage conversion DC to DC converter for distributed power system which improves overall system reliability. For controlling inverter along with Zsource network many PWM techniques are developed which are mainly giving interest to create a short through (ST).These ST attempt has been done for both sine PWM (SPWM) and space vector PWM (SVPWM) [24-25],[31-39]. The selective harmonics eliminations and thrid order harmonics elimination is a next technique to deal the inverter performance with respect to harmonics cancelations [26-28].

From the above discussion the high gain DC to DC converter is a suitable solution for electrical drive DC -link improvement. With the aim the high gain non-isolated DC to DC converter is connected with three phase six switch VSI with suitable shoot through option based PWM method. The proposed converter has an ability to increase the voltage five times and the counter winding arrangement ratio of the converter is help for the further increase of gain. Inn this interface the front end DC to DC converters inductors are charged by making the short circuit with inverter switching. The converter voltage gain is controlled by shoot through of the VSI switch (converter gain directly proportional to inverter shoot through). The proposed converter has a higher degree of freedom in their values of winding and output voltage. Hence, the DC-link voltage of the inverter can be extended in any level. The operation principle and modes of the proposed DC to DC Source tied VSI is analyzed and simulated using MATLAB-Simulink software simulation. The laboratory based small scale power circuit is developed with help of control algorithm. The entire implementation is done through PIC microcontroller platform. The deign Investigation, system simulation and experimentation confirming the proposed DC to DC converter tied VSI drive system.The working principle of the proposed transformer based DC to DC Source fed VSI is analysed and simulated using MATLAB/Simulink system software.

\section{PROPOSED DC TO DC TIED VSI FED DRIVE SYSTEM.}

A classic electrical dive motor drive system consists of a three-phase voltage source inverter drive as shown in Figure 1. Here, the input supply normally single phase AC supply and then rectifier connected with DC link of VSI drive. It is typical a single stage power conversion (DC to AC), hence the output voltage of the inverter is totally depends on rectifier output (DC-link of the inverter). The Figure 2 show the two stage power conversions. Here, the DC to DC converter is connected between inverter and rectifier for the improvement of DC -link voltage. This converter normally a buck-boost converter or boost converter. The 
dynamic load drive application these DC to DC converter demand only on boosting, hence the high gain boost converter is widely used.

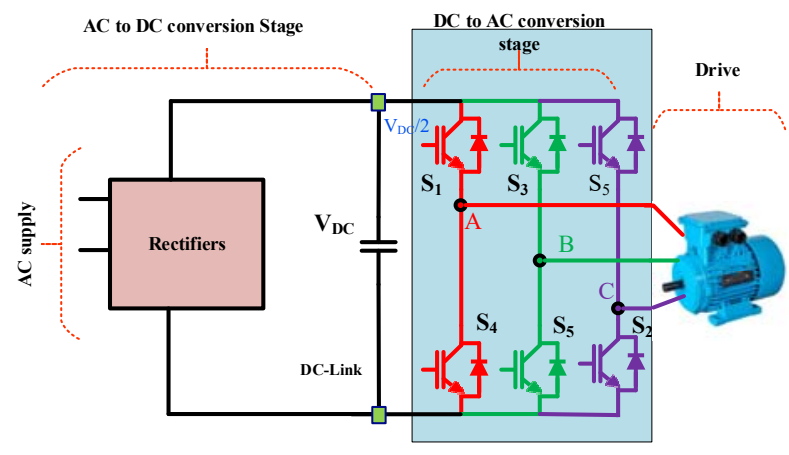

Figure 1. Electrical dive motor drive system

The Figure 2 show the two stage power conversions. Here, the DC to DC converter is connected between inverter and rectifier for the improvement of DC -link voltage. This converter normally a buckboost converter or boost converter. The dynamic load drive application these DC to DC converter demand only on boosting, hence the high gain boost converter is widely used.

The proposed power electronics interface is connect high gain non-isolated DC to DC converter with six switch inverter drive. The selective shoot through PWM method is used in this inverter for handling the DC to DC converter inductor storage and its boosting gain.

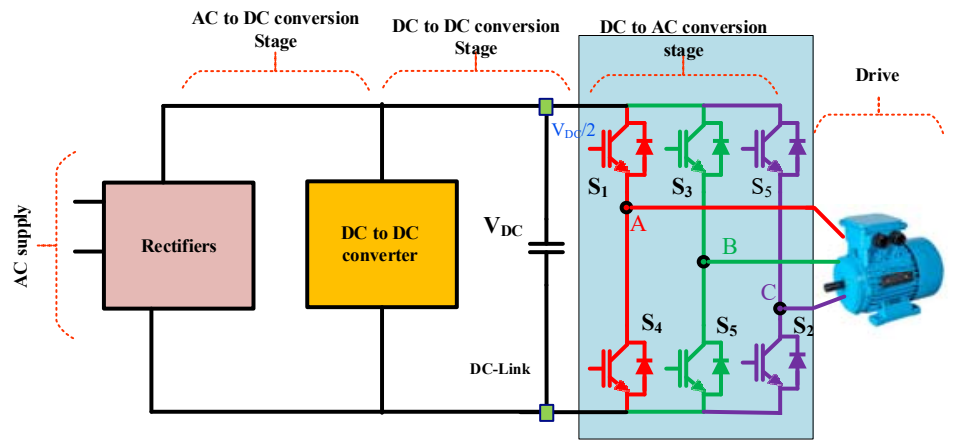

Figure 2. Electrical dive motor drive system

\section{DC TO DC CONVERTER}

\subsection{Coupled DC to DC converter}

A typical coupled DC to DC converter system as shown in Figure 3. The converter is consist of three magnetic coupled with different winging and inductor range. The input diode is used to connect input DC source and three coupled inductors. The capacitor is used to source the supply to output inductor in nonST states. The inverter bridge. Y-source network comprises of a passive diode, D, a winding coupled inductor $\left(\mathrm{N}_{1}: \mathrm{N}_{2}: \mathrm{N}_{3}\right)$ along with a capacitor, $\mathrm{C}$. The effectiveness of the inverter depends on the magnetic coupling tightness between the coupled inductors to keep away from any losses through leakage inductances.

The Y-source impedance can be elucidated by a simple single-switch converter as presented in the Figure 3. Bearing in mind the network working operation in ideal operating circumstances the converter will one or the other be in its ST state or non-ST state while discounting their leakage inductances. For the ST state, switch $\mathrm{S}$ is turned $\mathrm{ON}$ to short terminals 1 and 2, which in-turn, sources diode, $\mathrm{D}$ does not conduct (reverse bias). The converter is bring back to the non-ST state by turned 'OFF' the power switch ' $S$ ' with the diode, $\mathrm{D}$ conducting. To Averaging voltage across the inductance L1, 12 and L3, peak DC-link voltage $\left(\mathrm{V}_{12}=\right.$ $\mathrm{V}_{\mathrm{DC}}$ ) across terminals 1 and 2 in terms of input DC-link voltage to the VSI. However, this can be 
accomplished only with ideal operating condition, where the leakage inductances, $\mathrm{L}_{1}$ of the network is abolished or expressively reduced.

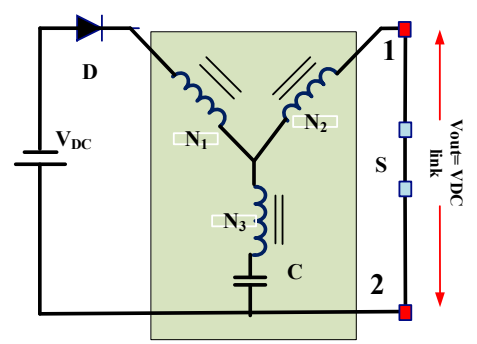

Figure 3. Magnetically coupled DC to DC converter [23]

\subsection{Modes of operation}

An intermediate equivalent circuit is introduced when the impedance source transits from non-ST state to ST state as shown in Figure 3(a). During non-ST state inductances are all discharging energies as well as current is therefore decreasing. The shunt switch $\mathrm{S}$ in the fig.3 is next shorted, which ideally, will lead to the ST circuit shown in Figure 3(c)

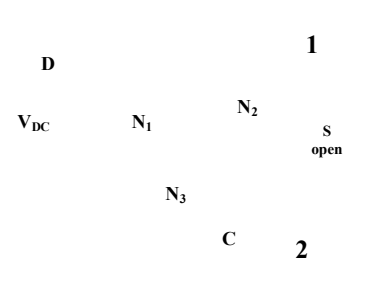

(a)

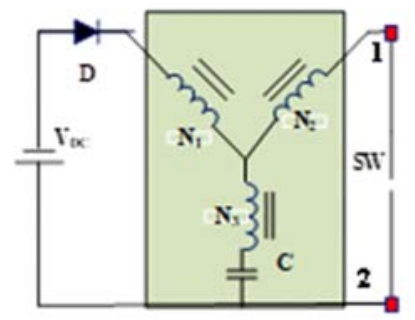

(b)

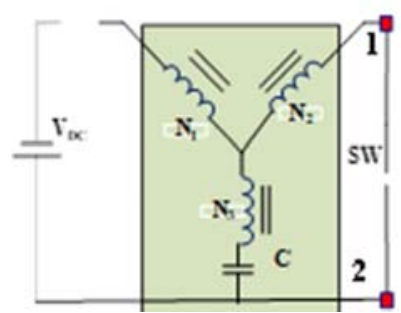

(c)

Figure 4 At Non-ST, D forward Biased, (b) At ST, D forward Biased, (c) At ST, D reversed Biased

Nevertheless, for the non-ideal case, an intermediate circuit shown Figure 3 (b) will be inserted for a short time interval, sourced by the rapid fall of the current through leakage inductance, $\mathrm{L}_{1}$ in $\mathrm{N}_{1}$, and rapid increases of currents during leakage inductances $\mathrm{N}_{2}$ and $\mathrm{N}_{3}$. The intermediate state ends only as the leakage current through $\mathrm{N}_{1}$ and diode D reduced to zero. For ST to non-ST transition, the network is in its ST state, when the switch, $\mathrm{S}$ is turned OFF, the network attached the source to the load and transits to non-ST state. Unlike the forward conduction, there is no intermediate state and the network enters its non-ST state directly with diode, D conducting, though its current may rises rapidly in excess of a short duration slightly than stepincreased. No reduction of the ST duration is therefore introduced by the reverse transition.

The current strained via this capacitive load be able to adapt to leakage current at instantaneous commutation, therefore neither voltage spikes nor limitations are practiced with capacitive loads. At less inductive nature, during the commutation from ST state to non-ST state, leakage currents caused by leakage inductance in $\mathrm{N}_{3}$ will be draped down to current directly, ensuing in high voltage in the circuit. Beside this momentary is not mitigated, it may affect $\mathrm{N}_{1}$ and $\mathrm{N}_{2}$ the leakage currents. Therefore a capacitive-snubber may be additional in order to transport downward between the load current and leakage current. expression as,

At the ST state interval $\mathrm{D}_{\mathrm{ST}}$, while the switch $\mathrm{S}$ is "ON" and diode, D is reverse-biased, the

$$
V_{C 1}+\frac{V_{L}}{k_{12}}-\frac{V_{L}}{k_{13}}=0
$$


Where, $\mathrm{k}_{13}=\mathrm{N}_{1} / \mathrm{N}_{3}, \mathrm{k}_{12}=\mathrm{N}_{1} / \mathrm{N}_{2}$, as well as $\mathrm{V}_{\mathrm{L}}$ is given as,

$$
V_{L}=V_{C 1}\left(\frac{k_{13} k_{12}}{k_{12}-k_{13}}\right)
$$

At non-ST state, the interval ( $\left.1-\mathrm{D}_{\mathrm{ST}}\right)$, diode, $\mathrm{D}$ is conducting is conducting source to the load, the KVL expression for

$$
\mathrm{V}_{\mathrm{L}}=V_{c 1}+V_{L}+\frac{V_{L}}{k_{12}}=V_{D C} ; V_{L}=\left[V_{D C}-V_{C}\right]\left(\frac{k_{12}}{1+k_{12}}\right)
$$

The, $\mathrm{V}_{\mathrm{C}}$ can be derived as,

$$
V_{C 1}\left(\frac{k_{13} * k_{12}}{k_{12}-k_{13}}\right)\left(d_{S T}\right)+\left\{\left[V_{D C}-V_{C}\right] \frac{k_{12}}{k_{12}+1}\right\}\left(1-d_{s T}\right)=0
$$

From the Eq.(5), finally $\mathrm{V}_{\mathrm{C}}$ is derived as,

$$
V_{C}=\frac{V_{D C}\left(1-d_{S T}\right)}{\left[1-\frac{n_{12} d_{S T}\left(1+n_{13}\right)}{\left(n_{12}-n_{13}\right)}\right]}
$$

At the non-ST states,

$$
\begin{gathered}
V_{d c_{-} \text {link }}=\frac{V_{\text {in }}}{1-F d_{S T}} ; F=\left(\frac{N_{3}+N_{1}}{N_{3}-N_{2}}\right) \\
\mathrm{N}_{1}+2 \mathrm{~N}_{2}>\mathrm{N}_{3} ; \mathrm{N}_{3}-\mathrm{N}_{2}>0 ; \mathrm{N}_{2}<\mathrm{N}_{3} ; \mathrm{N}_{3}>1 \\
0<1-F d_{S T} \leq 1 ; 0 \leq d_{S T} \leq d_{S T \text { max }}=1 / k \\
B F=\left(1-d_{S T}\right) / 0.896
\end{gathered}
$$

The proposed coupled DC to DC converter voltage gain diverges with respect to different winding factors, on the inductor. The ST duty cycles $\mathrm{D}_{\mathrm{ST}}$ is matched based on the gain requirement. The desired DC to DC converter gain with various arrangements of $F$ and $D_{\mathrm{ST}}$. Table 1. Shows $\mathrm{K}$ and $\mathrm{D}_{\mathrm{ST}}$ for selection of converter voltage gain. The table shows the clear combination of $\mathrm{F}, \mathrm{D}_{\mathrm{ST}}$, voltage gain, $\mathrm{N}_{1}: \mathrm{N}_{2}: \mathrm{N}_{3}$

The goal is to maximize coupling, and hence minimize leakage, which if not ensured, will lead to higher switching voltage in addition to a reduction in gain.

Table 1. Converter parameter $\mathrm{F}$, $\mathrm{d}_{\mathrm{ST}}$, voltage gain, $\mathrm{N}_{1}: \mathrm{N}_{2}: \mathrm{N}_{3}$

\begin{tabular}{llll}
\hline $\mathrm{K}$ & $0<\mathrm{d}_{\mathrm{st}}<\mathrm{d}_{\text {stmax }}$ & Voltage Gain, $\mathrm{G}_{\mathrm{v}}$ & $\mathrm{N}_{1}: \mathrm{N}_{2}: \mathrm{N}_{3}$ \\
\hline 2 & $0 \leq \mathrm{dst} \leq 1 / 2$ & $0.5 \mathrm{M}\left(1-2 \mathrm{dsT}^{-1}\right.$ & $1: 1: 3,2: 1: 4,1: 2: 5,3: 1: 5$ \\
3 & $0 \leq \mathrm{dst}^{-1} \leq 1 / 3$ & $0.5 \mathrm{M}\left(1-2 \mathrm{dss}^{-1}\right.$ & $1: 1: 2,3: 1: 3,2: 2: 4,1: 3: 5$ \\
4 & $0 \leq \mathrm{d}_{\mathrm{s}} \leq 1 / 4$ & $0.5 \mathrm{M}\left(1-2 \mathrm{dsT}^{-1}\right)^{-1}$ & $2: 1: 2,1: 2: 3,5: 1: 3,4: 2: 4$ \\
5 & $0 \leq \mathrm{d}_{\mathrm{sT}} \leq 1 / 5$ & $0.5 \mathrm{M}\left(1-2 \mathrm{~d}_{\mathrm{sT}}\right)^{-1}$ & $3: 1: 2,2: 2: 3,1: 3: 4,7: 1: 3$ \\
\hline
\end{tabular}

\section{SIMULATION STUDY}

The coupled DC to DC converter with six switch three phase VSI for EV drive. The inductor motor has chosen for EV motor. The Table 2, illustrations the software simulation parameter for proposed converter fed VSI drive. The three winding inductor transfer is designed by variable number of inductance winding values. The converter is designed with $565 \mathrm{~V} \mathrm{DC}$-link voltage. The input inverter voltage is considered as 
$100 \mathrm{~V}$ to $200 \mathrm{~V}$ range. The winding ratios $\mathrm{N}_{1}: \mathrm{N}_{2}: \mathrm{N}_{3}=1: 4: 8$ at a higher modulation index, $\mathrm{M}_{\mathrm{a}}=1$; while ST maximum duty ratio at $\mathrm{D}_{\mathrm{ST}}=0.236$.

Table 2. Simulation parameters

\begin{tabular}{cc}
\hline Parameters & Parameters values \\
\hline Drive rating, Transformer Turns, $\mathrm{N}_{1}, \mathrm{~N}_{2}, \mathrm{~N}_{3}$ & $330 \mathrm{v}$ to $440 \mathrm{~V}, 1.5 \mathrm{KW}, 1: 4: 8$ \\
Line to Line voltage $\left(\mathrm{V}_{\mathrm{L}}\right)$ & $300-440 \mathrm{~V}$ \\
VDC,Frequency (f), Switching frequency(fs) & $565 \mathrm{~V}, 50 \mathrm{~Hz}, 5 \mathrm{kHz}$ \\
Stator resistance (Rs) & $0.7 \Omega$ \\
Stator inductance $(\mathrm{Ls})$ & $0.0047 \mathrm{H}$ \\
Rotor resistance $(\mathrm{Rr})$ & $1.35 \Omega$ \\
Speed & 1300 to $1400 \mathrm{rpm}$ \\
$\mathrm{I}_{\mathrm{rms}}$ & $5 \mathrm{~A}$ \\
$\mathrm{~V}_{\mathrm{rms}}$ & $400 \mathrm{~V}$ \\
Torque $(\mathrm{T})$ & 6 to $8 \mathrm{Nm}$ \\
\hline
\end{tabular}

The Figure 5, displays the proposed DC to DC coupled inductor converter output voltage, when the input voltage is maintain as $120 \mathrm{~V}$. During the time winding factor of the converter is fixed as 4 . From the figure, it could see that the converter side capable to maintain the inverter Dc link voltage as 450 ( $\mathrm{V}_{\mathrm{DC}}$, DClink for VSI). Figure 6 shows the VSI voltage line-voltage and its maintaining the drive characteristics with maximum DC-link boosting utilization. From the results it seen that the VSI is able to give a stator voltage for the drive and giving the suitable voltage for the desired torque -speed. The voltage percentage THD is shown for the line-voltage. From the THD result is it could understand that, the proposed $3^{\text {rd }}$ harmonics is reduced the THD well below.

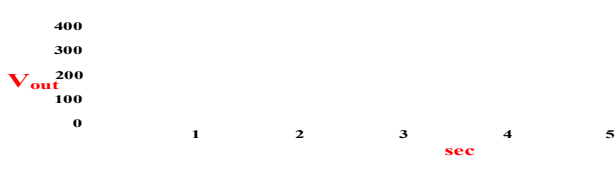

(a)

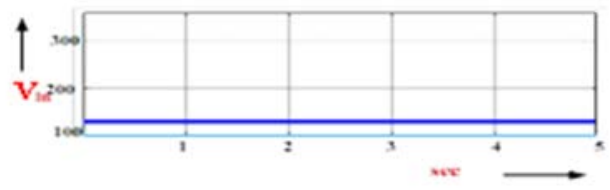

(b)

Figure 5. Simulation results of converter; (a). Output voltage $\left(\mathrm{V}_{\mathrm{DC}}\right)(\mathrm{b})$. Input of converter

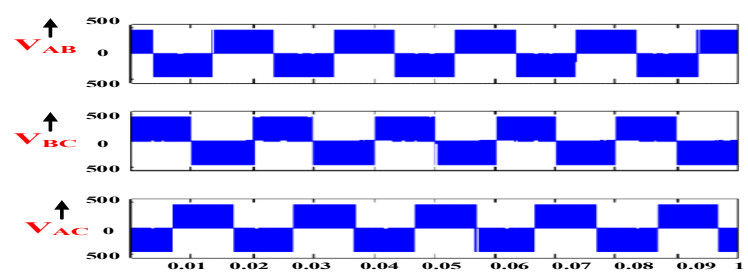

Figure 6. Simulation results of VSI drive - voltage for all line to line voltage

\section{EXPERIMENTAL RESULTS AND DISCUSSIONS}

The Figure 7 shows the laboratory scale experimental setup of the coupled inductor DC to DC converter fed three-phase VSI connected R load. For the investigation of the experimental verification for the proposed magnetic coupled DC to DC converter with six switches three-phase VSI, the 100W show sixswitch VSI is designed and collaborated with dsPIC microcontroller digital implementation platform. The TLP250 gate driver circuit is used for six MOSFETs. The VSI pulse width modulation is use SPWM and deployed in dsPIC for controlling inverter, the modulation index is fixed maximum as 0.1 . The dead time of inverter switch is fixed as 5.5 mircosec dead time. The inverter switching frequency is fixed as $5 \mathrm{kHz}$.

Int J Pow Elec \& Dri Syst, Vol. 10, No. 2, June 2019：645 - 652 


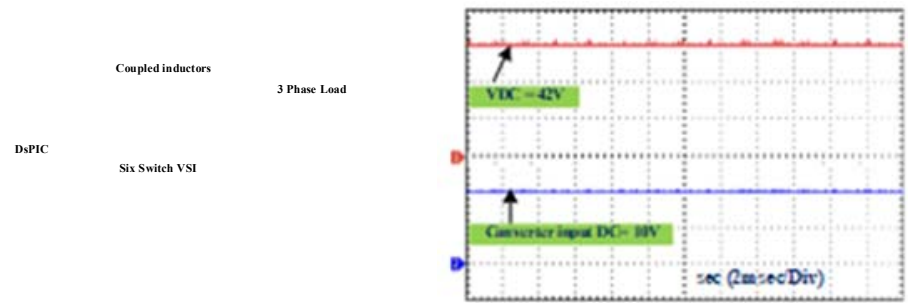

(a) (b)

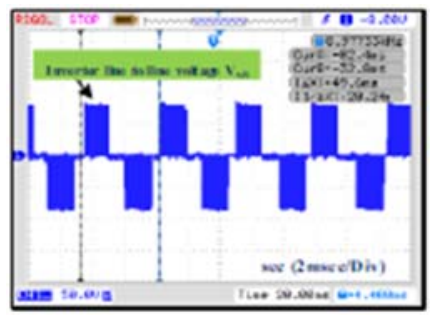

(c)

Figure 7 (a) Experimental setup, (b) Input voltage (Vin), output voltage ( $\left.V_{D C}\right)$, (c) Experimental Line voltage

The Figure 7(b) and Figure 7(c) show the Experimental results of converter output side and inverter load side. Here the experimentation is shown for fixed variable number of winding and inductance values to provide a $\mathrm{F}=4$ with inverter modulation index 0.9 and $\mathrm{D}_{\mathrm{ST}}=0.23$. From the Figure $7(\mathrm{~b})$ it can see that the converter is increasing the voltage from $10 \mathrm{~V}$ to $42 \mathrm{~V}$ (4.2 voltage gain). Hence as shown in this Figure 7(c), the inverter line to line voltage is DC-link voltage of $42 \mathrm{~V}$ and the inverter deliver $38 \mathrm{~V}$ RMS voltage for the 0.86 modulation index. The results are confirming the simulation results. From the converter and inverter results, the proposed coupled inverter tied VSI drive is able to maintain the drive characteristics with higher degree of freedom.

\section{CONCLUSION}

The presented high gain DC to DC coupled converter tied inverter drive able to provide very high voltage gain while operating at a higher ST duty and higher modulation index combinations. The different impedance combination voltage gain derivation and coupling networks analysis is clearly discussed and compared. The working principle of the proposed high gain DC to DC coupled converter tied inverter is investigated and studied through MATLAB/Simulink software simulated. The laboratory experimentation set up is developed via dsPIC controller and the results are carried out for entire operating conditions. The Study, simulation and experimentation validating the suggested high gain, high control degree for freedom converter fed VSI drive applications.

\section{REFERENCES}

[1] J. A. Peças Lopes, F. J. Soares, and P. M. Rocha Almeida, "Integration of electric vehicles in the electric power system," Proc. IEEE, vol. 99, pp. 168-183, Jan. 2011.

[2] C.Bharatiraja, P. Sanjeevikumar, PierluigiSiano, K.Ramesh, and S.Raghu., "Real Time Forecasting of EV Charging Station Scheduling for Smart Energy System", Energies, vol. 10, no. 377, pp. 1-14, March 2017.

[3] K. Kumar, R. Tiwari, N. R. Babu, S. Padmanaban, M. S. Bhaskar, and V. K. Ramachandaramurthy, "Analysis of high voltage-gain hybrid DC-DC power converter with RBFN based MPPT for renewable photovoltaic applications," 2017 IEEE Conference on Energy Conversion (CENCON), Oct. 2017.

[4] H. Cha, F. Z. Peng, and D. W. Yoo, "Distributed impedance network (Z network) dc-dc converter," IEEE Trans. Power Electron., vol. 25, no. 11, pp. 2722-2733, Nov. 2010.

[5] Wuhua Li; Xiangning He, "Review of Nonisolated High-Step-Up DC/DC Converters in Photovoltaic GridConnected Applications," IEEE Trans. Industrial Electronics, vol.58, pp. 1239-1250, May 2011.

[6] Savio A., D.; Juliet, V.; Chokkalingam, B.; Padmanaban, S.; K. Ramachandaramurthy, V. Design and Implementation of a Multiple Charging Point Adapted Hybrid Microgrid Powered Electric Vehicle Charging Station and Its Energy Management Strategy. Preprints 2018, 2018040226 (doi: 10.20944/preprints201804.0226.v1).

[7] C.Bharatiraja, S.Jeevananthan., Latha, R., "FPGA based practical implementation of NPC-MLI with SVPWM for an autonomous operation PV system with capacitor balancing", in International Journal of Electrical Power and Energy Systems, vol. 61, pp.489-509, Oct 2014

[8] M. Tariq, M. T. Iqbal, M. Meraj, A. Iqbal, A. I. Maswood, and C. Bharatiraja, "Design of a proportional resonant controller for packed U cell 5 level inverter for grid-connected applications," 2016 IEEE International Conference on Power Electronics, Drives and Energy Systems (PEDES), Trivendram, kerala, India. 14 -17 Dec 2016.

[9] C. Bharatiraja, S. Padmanaban, P. Siano, Z. Leonowicz, and A. Iqbal, "A hexagonal hysteresis space vector current controller for single Z-source network multilevel inverter with capacitor balancing," 2017 IEEE International Conference on Environment and Electrical Engineering and 2017 IEEE Industrial and Commercial Power Systems Europe (EEEIC / I\&CPS Europe), Milan, Italy,6-9 June 2017.

[10] P. C. Loh, D. M. Vilathgamuwa, C. J. Gajanayake, Y. R. Lim, and C. W. Teo, "Transient modeling and analysis of pulse-width modulated Z-source inverter," IEEE Trans. Power Electron., vol. 22, no. 2, pp. 498-507, Mar. 2007. 
[11] F. Z. Peng, "Z-source inverter," IEEE Trans. Ind. Applicat., vol. 39, no. 2, pp.04-510, Mar/Apr. 2003.

[12] M. K. Nguyen, Y. C. Lim, and Y. G. Kim, “TZ-source converters,” IEEE Trans. Ind. Electron., vol. 60, no. 12, pp. 5686-5695, Dec. 2013.

[13] M. Adamowicz, R. Strzelecki, F. Z. Peng, J. Guzinski, and A. H. Rub, "New type LCCT-Z-source converters," in Proc. EPE 2011, Sept. 2011 pp. 1-10.

[14] M. Adamowicz, J. Guzinski, and P. Stec, "Five-phase EV drive with switched-autotransformer (LCCAt) converter," in Proc. VPPC 2014, Oct. 2014, pp. 1-6.

[15] Y. P. Siwakoti, P. C. Loh, F. Blaabjerg, S. J. Andreasen, and G. E. Town, "Y-Source impedance network based boost DC/DC converter for distributed generation," IEEE Trans. Ind. Electron., vol. 62, no. 2, Feb. 2015.

[16] T.K.S Sathayanarayanan, M Ramasamy, C Bharatiraja, JL Munda "Modelling, Impedance Design, and Efficiency Analysis of Battery Assists PV tied Quasi-Z source inverter", in International Journal of Power Electronics and Drive System (IJPEDS)s, vol.3, no.7, pp. 816-825, Dec 2016.

[17] H. Cha, F. Z. Peng, and D. W. Yoo, "Distributed impedance network (Z network) dc-dc converter," IEEE Trans. Power Electron., vol. 25, no. 11, pp. 2722-2733, Nov. 2010.

[18] Y. Tang, S. Xie, and C. Zhang, "Z-source ac-ac converters solvingcommutation problem," IEEE Trans. Power Electron., vol. 22, no. 6, pp.2146-2154, Nov. 2007.

[19] P. C. Loh, D. Li, and F. Blaabjerg, "T-Z-source converters," IEEE Trans. Power Electron., vol. 28, no. 11, pp. 4880-4884, Nov. 2013.

[20] R. Strzelecki, M. Adamowicz, N. Strzelecka, and W. Bury, "New type T-source converter," in Proc. CPE 2009, May 2009, pp. 191-195.

[21] W. Qian, F. Z. Peng, and H. Cha, "Trans-Z-source converters," IEEE Trans. Power Electron., vol. 26, no. 12, pp. 3453-3463, Dec. 2011.

[22] Y. P. Siwakoti, F. Blaabjerg and P. C. Loh, "New magnetically coupled impedance (Z-) Source networks," IEEE Trans. Power Electron., vol. 31, no. 11, pp. 7419-7435, June 2015.

[23] Y. P. Siwakoti, F. Z. Peng, F. Blaabjerg, P. C. Loh and G. E. Town, "Impedance source network for electric power conversion - Part I: A topological review," IEEE Trans. Power Electron., vol. 30, no. 2, pp. 699-716, Feb. 2015.

[24] C. Bharatiraja and J. L. Munda, "Simplified SVPWM for Z Source T-NPC-MLI including neutral point balancing," 2016 IEEE Symposium on Computer Applications \& Industrial Electronics (ISCAIE), Penang, Malaysia,30- 31 May

[25] Santhakumar, C., Shivakumar, R., Bharatiraja, C., Sanjeevikumar, P. "Carrier shifting algorithms for the mitigation of circulating current in diode clamped MLI fed induction motor drive ", in International Journal of Power Electronics and Drive Systems, vol.8, no.2, pp. 844-852, June 2017

[26] Y. P. Siwakoti, P. C. Loh,F. Blaabjergand G. Town, "Y-Source Impedance Network," in Proc. APEC 2014, Fort Worth, TX, pp.3362-3366, Mar. 2014

[27] C.Bharatiraja, S.Raghu, Anathraj, Prabathkumar "Analysis and simulation of magnetically coupled Y shape impedance source inverter", Indian Journal of Science and Technology, Volume 9, Issue 44, pp. 1-7,2016

[28] C. Bharatiraja, S. Jeevananthan, and J. L. Munda, "A Timing Correction Algorithm-Based Extended SVM for Three-Level Neutral-Point-Clamped MLI in Over Modulation Zone," IEEE Journal of Emerging and Selected Topics in Power Electronics, vol. 6, no. 1, pp. 233-245, Mar. 2018.

[29] Y. Tang, S. Xie, and C. Zhang, "An improved Z-source inverter," IEEE Trans. Power Electron., vol. 26, no. 12, pp. 3865-3868, Dec. 2011.

[30] C. Bharatiraja, T. B. Prasad, and R. Latha, "Comparative realization of different SVPWM schemes in linear modulation using FPGA," 2008 IEEE Region 8 International Conference on Computational Technologies in Electrical and Electronics Engineering, Jul. 2008.

[31] C.Bharatiraja, S. Jeevananthan, S, R. Latha, and V.Mohan, "Vector selection approach-based hexagonal hysteresis space vector current controller for a three phase diode clamped MLI with capacitor voltage balancing," IET Power Electronics., vol. 9, no. 7, pp. 1350-1361, June 2016.

[32] T. K. . Sathayanarayanan, M. Ramasamy, C. Bharatiraja, and J. Munda, "Modelling, Impedance Design, and Efficiency Analysis of Battery Assists PV tied Quasi-Z source inverter," International Journal of Power Electronics and Drive Systems (IJPEDS), vol. 7, no. 3, p. 816, Sep. 2016.

[33] C Bharatiraja, JL Munda, Ishan Vaghasia, Rajesh Valiveti, P. Manasa, "Low cost Real Time Centralized Speed Control of DC Motor Using Lab view -NI USB 6008", in International Journal of Power Electronics and Drive Systems, vol.3, no.7, pp. 656-664, Dec 2016.

[34] C. Bharatiraja, A. Ravi, S. Banerjee, A. Chakraborty, A. Anupam, and A. Menon, "A Hybrid Cascaded Multilevel Inverter with Diode Assisted Boosting Network,” Energy Procedia, vol. 117, pp. 1024-1031, Jun. 2017.

[35] C. Bharatiraja, and R. Latha, " A 3 - Dimensional Svpwm Algorithm, Its FPGA -Implementation for Multilevel Inverters ", in Journal of Electrical Engineering, vol.14, Issue 2, Pages 61-70, 2014.

[36] C.Bharatiraja, Mohammad Shabin, "A Novel reduced switch single source MLI topology with variable input overvoltage control", in Procedia Engineering, vol.64, pp.205-214, 2013

Int J Pow Elec \& Dri Syst, Vol. 10, No. 2, June 2019: $645-652$ 